\title{
Geothermal Energy Utilization in the Kamojang Nature Reserve, West Java, Indonesia
}

\author{
Endes Nurfilmarasa Dachlan, Vella Putiksari, Lilik Budi Prasetyo \\ Department of Forest Resources Conservation and Ecotourism, Faculty of Forestry, Bogor Agricultural \\ University, Indonesia. Darmaga Campus IPB, Bogor \\ Corresponding E-mail: endesndahlan@gmail.com
}

\begin{abstract}
Geothermal energy activities are allegedly disturbing Kamojang Nature Reserve by clearing the forest. Actually, the national park according to the Law No. 41 of 1999, must not jeopardize the preservation of germplasm in it. Meanwhile, the utilization of geothermal power plant in the area is also required to meet the electricity demand in Indonesia. Land clearing as one of the activity of exploration and exploitation of geothermal coupled with the increasing of human's activity inside the forest caused widespread deforestation. Since there is a geothermal energy project inside the Kamojang Nature Reserve, then the aim of this study is to analysis the land cover change at Kamojang Nature Reserve from year 2000 until 2011. The research showed that the type of land cover was dominated by forest for about 4231.3 ha with forest cover percentage around $51.17 \%$. Aside of that, the land cover change caused by exploration and exploitation of Pertamina Geothermal Energy was 60.2 ha (8.90\%), while the changes caused by human activities was 614.46 ha (91.10\%). Based on these results, replanting had been done to overcome the worse effect from each activities. The extent of reforestation and enrichment conducted by PGE was 680.58 ha by involving the society who live in surrounding area.
\end{abstract}

Key Words: Deforestation, Geothermal, Land cover, Nature reserve.

\begin{abstract}
Abstrak
Aktivitas pemanfaatan panas bumi berpotensi mengganggu kelestarian Cagar Alam Kamojang dalam bentuk kerusakan hutan. Pemanfaatan panas bumi di Cagar Alam menurut Undang-Undang Nomor 41 Tahun 1999 tidak boleh mengganggu kelestarian plasma nutfah yang ada di dalamnya. Sementara itu, pemanfaatan panas bumi diperlukan untuk pembangkit tenaga listrik untuk memenuhi kebutuhan listrik di Indonesia. Pembukaan lahan akibat kegiatan eksplorasi dan eksploitasi panas bumi ditambah dengan meningkatnya aktivitas manusia di dalam hutan mengakibatkan deforestasi yang meluas. Tujuan penelitian ini adalah untuk menganalisis perubahan tutupan lahan di Cagar Alam Kamojang dari tahun 2000 sampai 2011. Hasil penelitian menunjukkan bahwa jenis tutupan lahan didominasi oleh hutan sekitar 4.231,3 ha dengan persentase tutupan hutan sekitar 51,17\%. Selain itu, perubahan tutupan lahan yang disebabkan oleh Pertamina Geothermal Energy (PGE) adalah 60,2 ha (8,90\%), sedangkan perubahan yang disebabkan oleh aktivitas manusia adalah 614,46 ha (91,10\%). Untuk mengatasi terjadinya perubahan tutupan lahan, penanaman telah dilakukan untuk mengatasi efek buruk dari masing-masing kegiatan. Luasan areal reboisasi dan pengayaan yang dilakukan oleh PGE adalah 680,58 ha dengan melibatkan masyarakat yang tinggal di daerah sekitarnya.
\end{abstract}

Kata kunci: Deforestasi, Panas Bumi, Perubahan Tutupan Lahan, Cagar Alam.

\section{Introduction}

The decreasing of functions of forest resources has been occurred not only for the function of forest as a wood producer, but also the function of forest as supporting of life (Haeruman, 2005). Land cover change is important to be studied. Some researches on land cover changes among others conducted by Suryantoro (2004), Gunawan (2003), Haryadi (2009) and Nahib (1998).

The nature reserve is a nature reserve zone due to its natural state has peculiarities of plants, animals, and the ecosystem or particular ecosystem that need to be protected. Kamojang 
Nature Reserve is one of the conservation forest area which has its peculiarities according to the Law No. 41 of 1999. Kamojang nature reserve has experienced not only various physical pressures, but also accommodate the exploration of geothermal energy source since 1918.

Development of exploration and exploitation of geothermal energy as a source of national energy needs to be enhanced regarding the utilization of geothermal as power plant can support the reduction of green house gas emissions. It will replace the use of fossil energy, such as oil, natural gas and coal because the energy derived from geothermal are renewable and more environmentally friendly (Nawir 2011). Aside of that, the utilization of geothermal energy can also overcome the problems of domestic energy, especially in remote area, which is expected to sustain the national energy security in the future in order to meet the electrical energy needs in Indonesia.

Concerning the benefits of geothermal energy due to the national interest and the increasing of energy needs in the future, then the utilization of geothermal energy in Kamojang Nature reserve is important to be explored. According to Rachmawati (2012) in order to improve geothermal energy in the future, various efforts must be concerned that include the following: 1) aspect of preservation and the increasing of high conservation values (biodiversities and habitats, environmental services, unique ecosystems, and welfare of societies), 2) development of geothermal needs to consider the integration of social, economic, and environment aspect due to the planning of each activities to anticipate every risks that threatening its sustainability, and 3) recognition of the rights of local residents should also be considered to ensure their participation from planning to implementation. Beyond the needs of the electricity demand, the attention is also focused on the physical pressure that has appeared in forest land, such as the encroachment of land, firewood collection, timber theft, illegal logging and forest fire by the society (Dwipayanti et al. 2009). Researcher from many countries agreed that the main factors of deforestation are the population growth (Entwisle et al. 2006, Tahir et al. 2012), the need of firewood and building materials (Hirsch 1987), conversion of forest land to agriculture (Casse et al. 2002; Lindstorm et al. 2012; Scrieciu 2006), poverty, the lack of economic alternatives, and the lack of law enforcement (Horowitz 1997), and unclear area boundaries (Widada 2008). In the Kamojang nature reseve, the decreasing of forest cover is related to the presence of geothermal mining activities by PGE.

Since the exploration and exploitation proceed in the Kamojang Nature Reserve, it has been occurred a changing in ecological aspect. Land clearing caused various effect of ecological disruption, such as plants or animals that are not native as well as habitat fragmentation. On the other hand, the activities of land clearing, such as road construction stimulates the society surrounding area to get into the nature reserve (Trombulak and Frissel 2000). Based on these problems, land clearing as one of the activity of exploration and exploitation of geothermal coupled with the increasing of human's activity inside the forest caused widespread deforestation. In addition, it will effect the role of forest as providers of environmental services.

Land Use/Land Cover (LULC) changes was significant contributor to a range of environmental problem. It has been widely accepted that LULC change in an area is a result of the complex interactions between driving factors (Kelarestaghi and Jeloudar 2009). Reis (2008) explained that LULC alterations (based especially on human activities), negatively effect the patterns of 
climate, the patterns of natural hazard and socio-economic dynamics in global and local scale. Therefore, available data on LULC changes can provide critical input to decisionmaking of environmental management and planning the future. Mapping LULC changes at regional scales was essential for a wide range of applications. Several researches on land cover study among others conducted by: Nahib dan Wijaya (1998), Gunawan (2003), Haryadi (2009), , Rushayati et al. (2010), Dachlan (2011) dan Rushayati et al. (2011). This research lifted the conflict analysis of land cover change between conservation of nature reserve and utilization of geothermal energy in the Kamojang Nature Reserve as an effort to improve the condition of forest cover. For achieving the forest sustainability, various ways must do due to the decreasing of human's activities inside the nature reserve. The aim of this study is to analysis the land cover change at Kamojang Nature Reserve from year 2000 untill 2011.

\section{Research Method}

\section{a. Study Location}

This study conducted in the Kamojang Nature Reserve with area of 7067.196 Ha. Geographically, Kamojang Nature Reserve is situated in two districts of Garut and Bandung Regency, West Java Province, Indonesia between South Latitude $7^{\circ} 17^{\prime}$ and East Longitude $107^{\circ} 31^{\prime}-108^{\circ} 5^{\prime}$. According to the administration, these area belong to the working area Section KSDA Garut, West Java KSDA Great Hall.

The specific locations of observation are A) Blok Pasirjawa, Blok Cihejo, Blok Cipateungteung which is located near to the Laksana Village; B) The frontier area of Kamojang Nature Reserve and Cisarua Village; C) The frontier area of Kamojang Nature Reserve and Sukarame Village (See Fig. 1). Those locations had been selected according to the trace of encroachment massively that occurred inside the nature reserve.

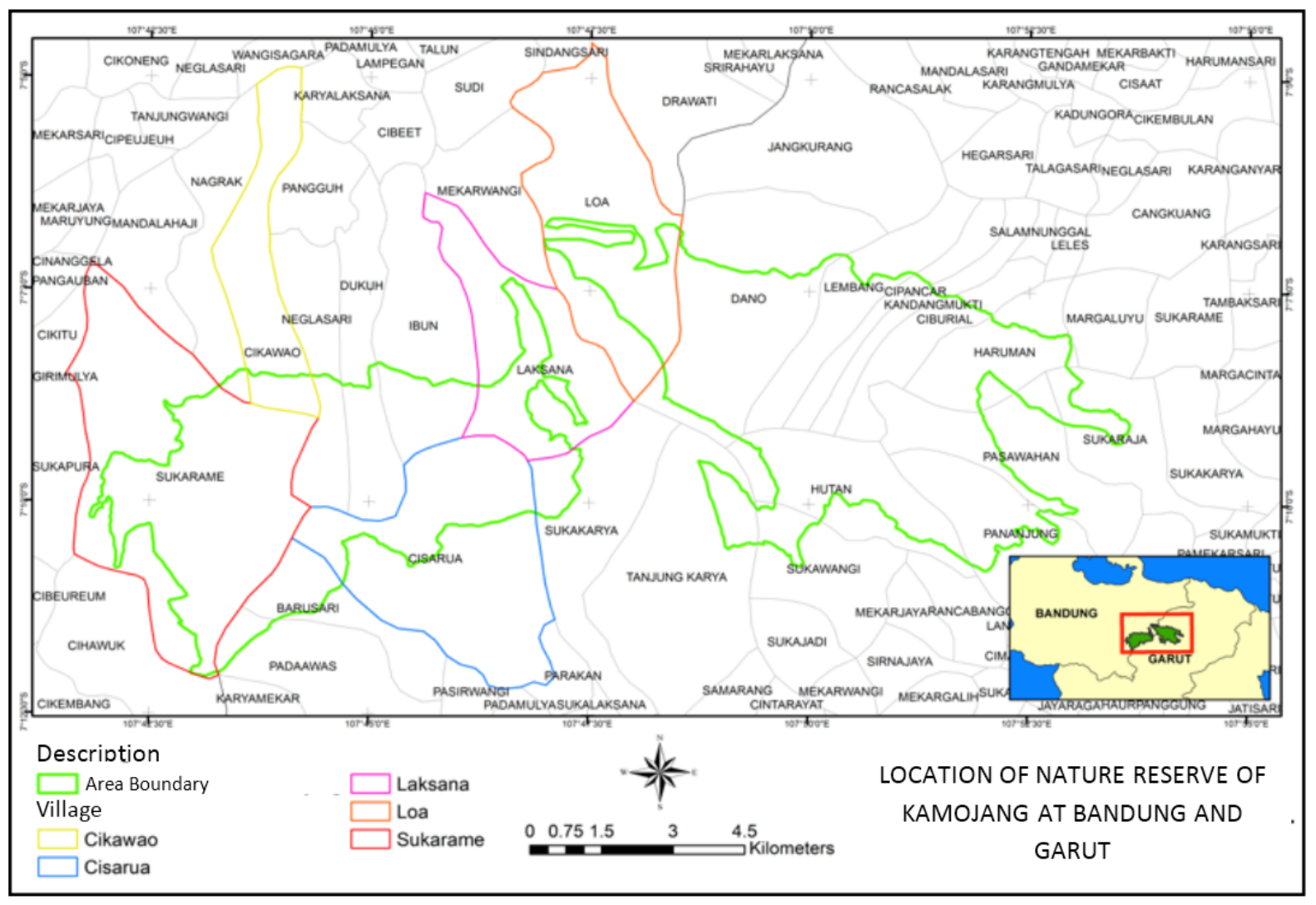

Figure 1. Map of Research Location 


\section{b. Data Collection}

Data source derived from interview and observation as primary data. While the secondary data derived from literature and related institution, such as PPLH IPB, BIOTROP, PT PGE and BKSDA. Image pre-processing, image classification and change detection were performend using ERDAS IMAGINE 9.1, while GIS analysis was carried out using ArcGIS 10.1. Tahir et al. (2013) explained that remote sensing and GIS techniques offered an important means to detect and analyze the temporal changes especially in detecting changes on a broad landscape quickly and efficiently.

\section{c. Data Analysis}

Geometric correction was required to avoid geometric distortions, by establishing te relationship between the image coordinate system and the geographic coordinate system through calibration data sensor, measured data position and altitude, ground control points, and atmospheric conditions (Lubis and Nakagoshi 2011). Dhorde et al. (2012) revealed that the use of LULC involved at least two periods of time. This study was using Landsat Thematic Mapper (TM) imagery dated on October 9, 2000 (Figure 2) and Landsat Enhanced Thematic Mapper Plus (ETM+) imagery dated on August 21, 2011 (Figure 3). Digital data of Landsat imagery path 121 and row 65 were utilized as the main data in this study. Since the spatial resolution of these two images were different, they were further resampled and rescaled to $30 \mathrm{~m}$ resolution.

All information extracted from remotely sensed data is obtained in the consistent technical flow: the geometric rectification, image registration and images matching with each other. For supporting images analysis, some ancillary data were used in this study including ground truth data, map of administrative boundaries of village, the extent of area, maps of height and slope, map of Indonesia (scale of 1:50.000) using the Universal Transvere Mercator (UTM) coordinate system, Datum World Geodetic System (WGS) 1984, zone 49 South. The maps of elevation, slope, and aspect were derived and classified by using Digital Elevation Model (DEM). All of the ancillary data were used to assist the training area selection in image classification and for collecting the reference data in assessing classification accuracy. Radiometric calibration was also performed on the images through the conversion of $\mathrm{DN}$ units into spectral radiance and then further into spectral reflectance units at sensor. The geometrically corrected images were finally subset to the area of interest of study site.

The supervised classification technique with Maximum Likelihood Classifier (MLC) was employed to obtain a LULC classified map for both the images. The MLC assumes that the pixels of unknown category membership have a certain probability of belonging to a particular category. The maximum likelihood method was used for the land use classification in ERDAS IMAGINE 9.1 software. Besides, the supervised classification requires training areas for each category. The training areas were decided on the basis of visual interpretation. Those were used to define spectral reflectance patterns/signature of each LULC category. The signatures would then be used by classifier to group the pixels into visual analysis on the images through displaying RGB combination (Bands 543) and also supporting by the ancillary information drom the forest cover maps, Google Earth and the prior knowledge of the author on the study area which were gained from the field survey. 


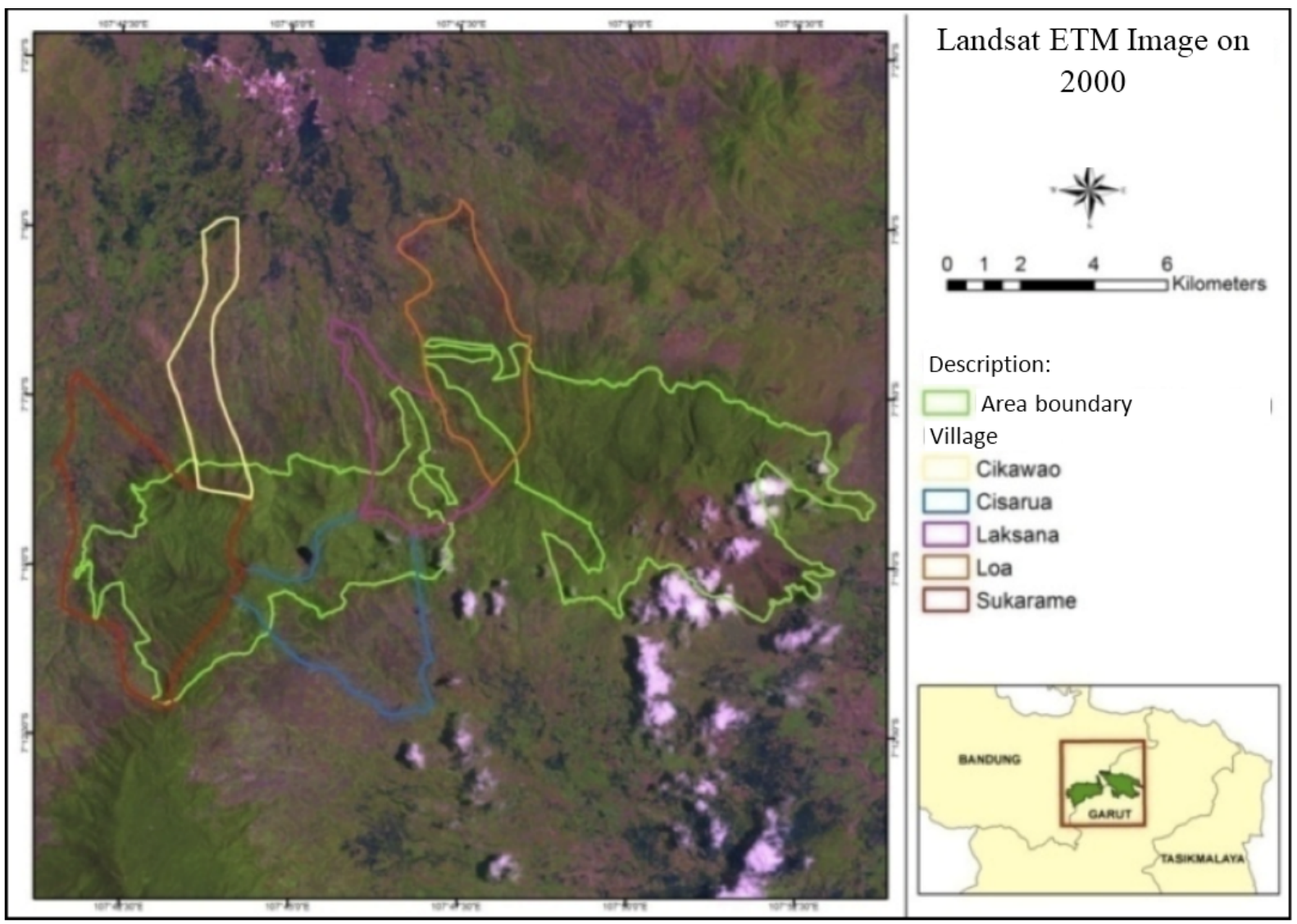

Figure 2. Landsat Image 7 ETM Recorded October 9, 2000

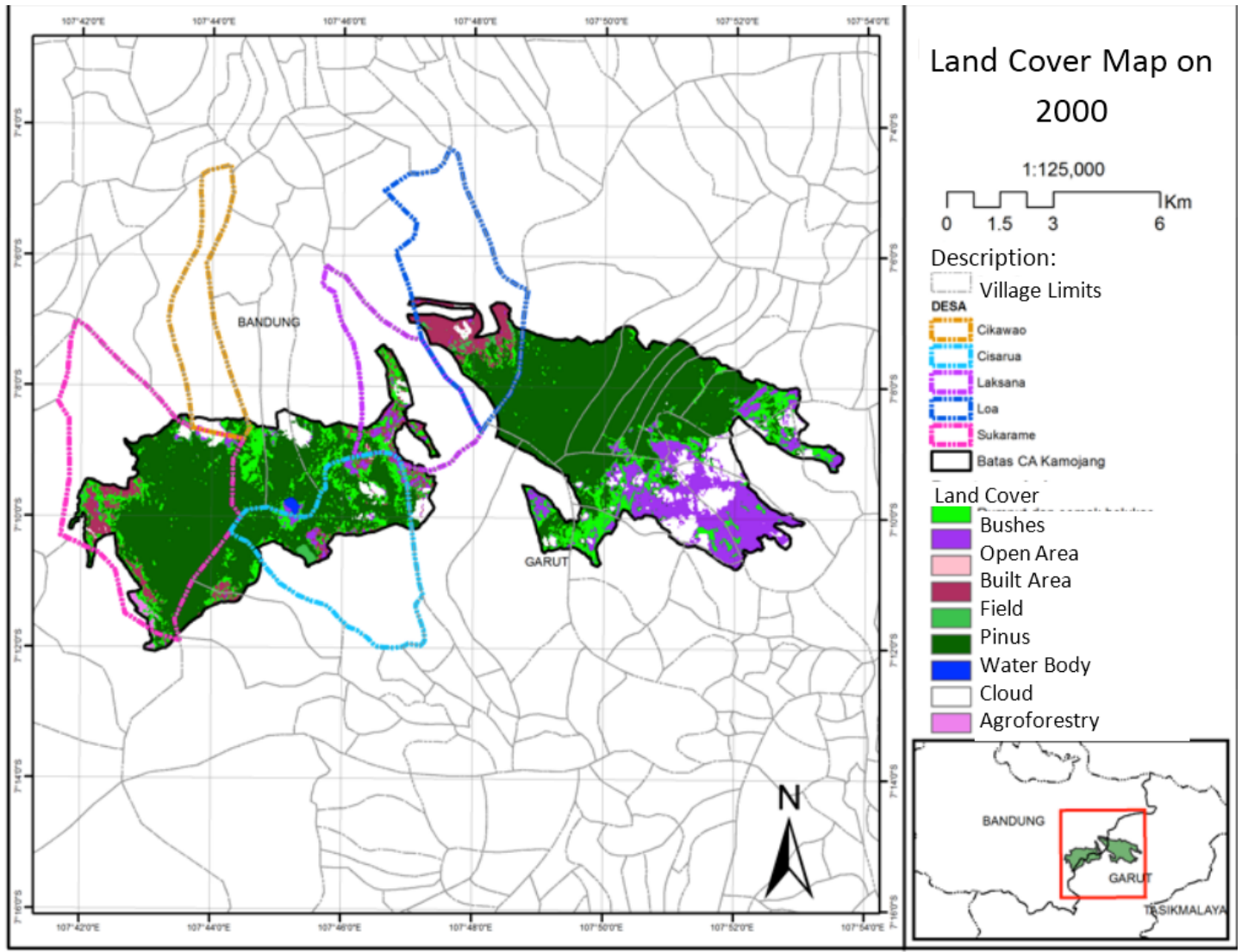

Figure 3. Landsat Image 7 ETM+ Recorded August 21, 2011 


\section{Results and Discussions}

\section{a. Land Use/ Land Cover Change During 2000-2011}

Lunetta et al. (1991) revealed that the most common way to represent the thematic or classification accuracy of remotely sensed data was in the form of an error matrix. In this research, accuracy assessment by overall classification accuracy was $85.42 \%$ and kappa accuracy was $80.45 \%$. Based on these assessment results, the image data classification can be used because the value accuracy more than $80 \%$. Dhorde et al. (2012) stated that overall accuracy obtained for both the images is above $80 \%$ and the kappa statistics is above 0.75 , indicating the classification accuracy to be reasonably good to excellent.

Generally, Kamojang Nature Reserve have been classified into 9 categories: (1) primary and secondary forests; (2) pine plantation; (3) built-up land; (4) agricultural land; (5) grass and shrubs; (6) agroforestry; (7) water; (8) open land; and (9) no data (See Table 1).

Table 1. Definition of Each Land Cover Categories

\begin{tabular}{|c|c|c|}
\hline No & Categories & Definition \\
\hline 1 & Agroforestry & Agricultural crop that combined with forestry crops \\
\hline \multicolumn{3}{|l|}{2} \\
\hline & Grass and shrubs & $\begin{array}{l}\text { Dry land area that has been covered by a variety of the heterogeneous or } \\
\text { homogeneous natural vegetation with the density levels rarely up to tightly }\end{array}$ \\
\hline 3 & Water & $\begin{array}{l}\text { An area covered by open water such as ocean, rivers, ponds, reservoir, artificial } \\
\text { aquacultures, lake, and fishponds }\end{array}$ \\
\hline 4 & Primary forest & $\begin{array}{l}\text { An area covered by dense trees with relatively darker green color and has not } \\
\text { suffered human intervention or logging }\end{array}$ \\
\hline 5 & Secondary forest & Forests that have undergone human intervention and logging \\
\hline 6 & Pine Plantation & An area cultivating pine without replacement crop for two years. \\
\hline 7 & Agricultural Land & $\begin{array}{l}\text { Dryland farming planted with food crops, vegetable, bare land and does not } \\
\text { require extensive irrigation, require human intervention to support the survival }\end{array}$ \\
\hline 8 & Built-up land & $\begin{array}{l}\text { An area that has undergone substitution in natural or semi-natural land cover } \\
\text { become the artificial land cover which is waterproof and relatively permanent }\end{array}$ \\
\hline 9 & Open land & A land without land cover, both natural, semi-natural or artificial \\
\hline
\end{tabular}

According to the land cover data in 2000, the type of landcover is dominated by primary and secondary forests with the extent of area $4,861.17$ ha $(58.79 \%)$. It was followed by grass and shrubs (14.56\%), open land $(11.69 \%)$, field $(6.55 \%)$, pine plantation $(0.54 \%)$, agricultural land $(0.39 \%)$, water $(0.15 \%)$ and built-up land $(0.008 \%)$. However, based on the interview to head of Section KSDA Garut, in year 2000 was in a very poor conditions as a result of the economic crisis in the past 1998. During the economic crisis, community openly plant vegetable crops such as cabbage, potatoes and sweet potatoes on the land around the geothermal mining and in the reserve area. This problems leads into a large pressure of encroachment. It can be seen by a trace of pioneer plants and bushes during the observation (See Figure 4).

Meanwhile, according to the land cover data in 2011, the type of landcover still dominates by a primary and secondary forests but the 
percentage of forest has increased to 4890.78 ha $(59.15 \%)$. It was followed by grass and shrubs $(15.44 \%)$, open land $(12.57 \%)$, field $(2.60 \%)$, agricultural land $(2.10 \%)$, water body $(0.17 \%)$, pine plantation $(0.40 \%)$, and built up-land (0.33\%). The increasing of forest land is in line with the increasing of grass and shrubs. These results indicate the increasing of forest has been followed by the activity of the offender for 11 years (See Figure 5).

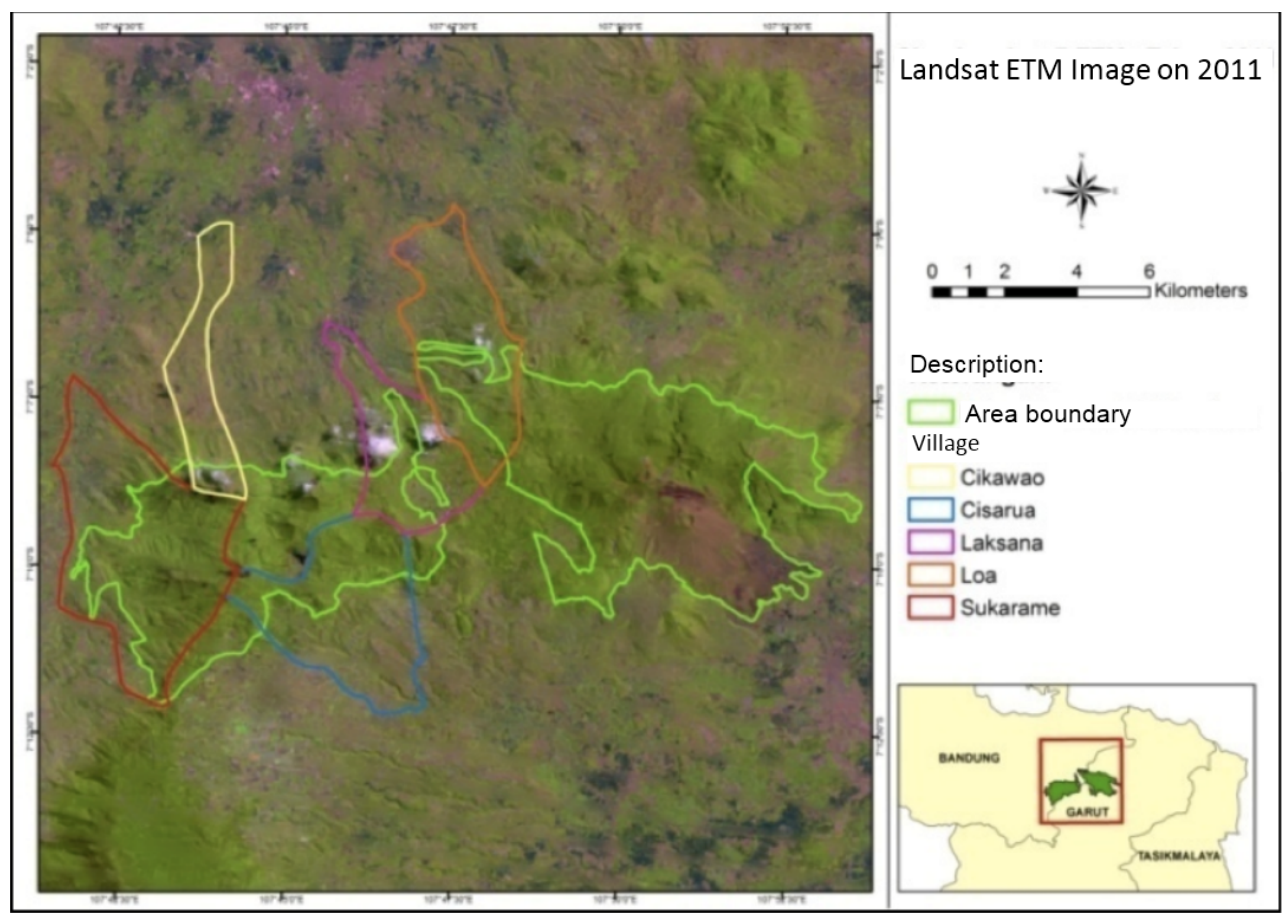

Figure 4. Spatial Distribution of Land Cover/Land Use Change in 2000

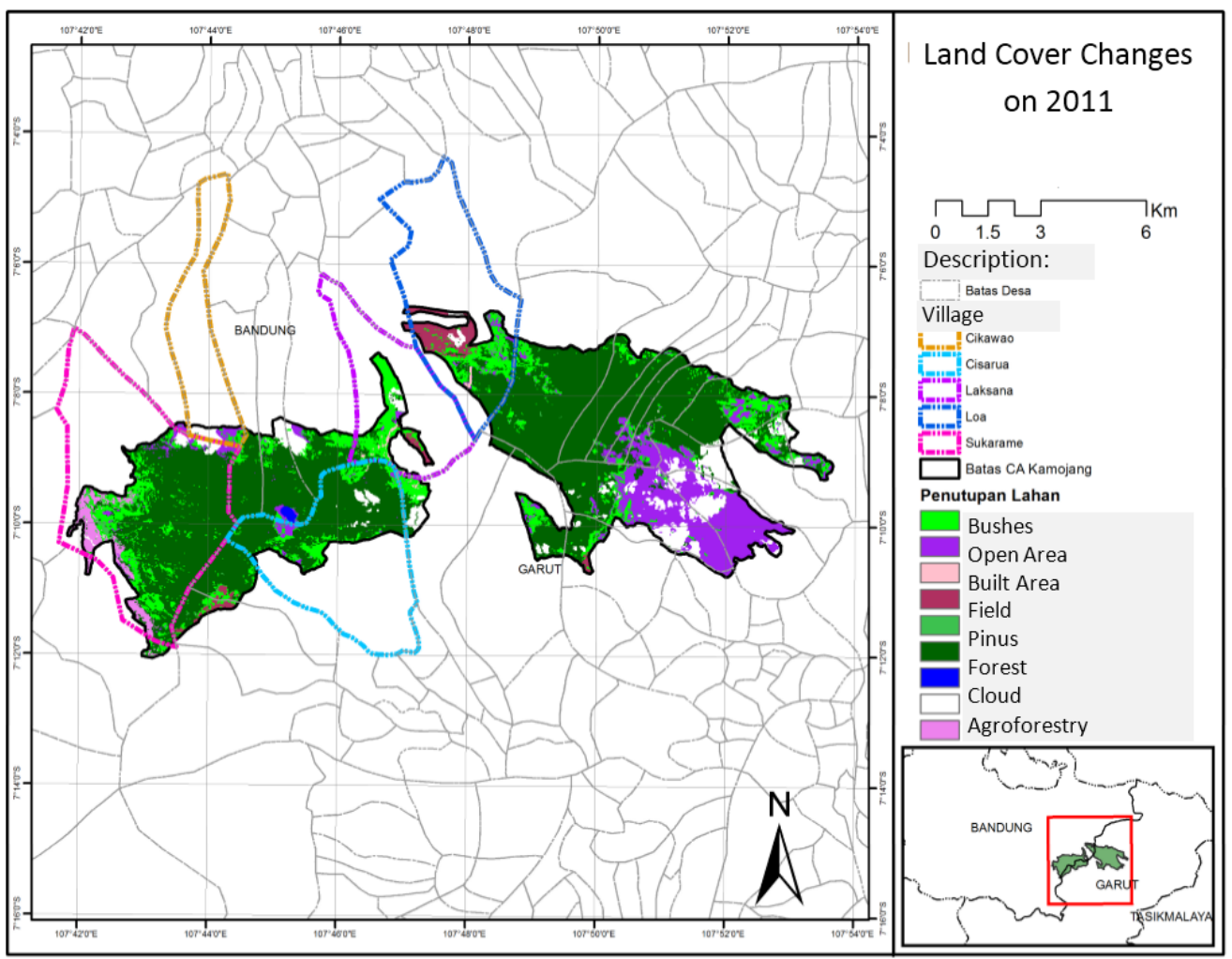

Figure 5. Spatial Distribution of Land Cover/Land Use Change in 2011 
Based on landsat image interpretation in 2000-2011, it is known that the extent of agricultural land has increased to 141.84 ha $(1.72 \%)$, but field has decreased to 327.15 ha $\quad(-3.96 \%)$. According to head of section KSDA Garut, some people also change their pattern of farming; from cultivation into plant an agricultural crops and other forest covers. Besides, the presence of PGE inside the reserve area causing wide open access in it and also can be utilized by the seekers and illegal loggers to get into the forest and caused the pressure on forests and land greater. This further allows the public to clear the forest land, both small scale and large scale which leads into a large pressure of encroachment. As Suhendang (2002) revealed that the extent of forest area was fixed and the carrying capacity was limited, but the human needs would increase and cause the decreasing of the extent of the forest and its quality (See Table 2). Figure 6 showed the graph percentage of Land Cover Change in 2000 and 2011.

Table 2. Land Cover Change in the Kamojang Nature Reserve in 2000-2011

\begin{tabular}{llcccccc}
\hline \multirow{2}{*}{ No } & \multicolumn{2}{c}{ Land Cover } & \multicolumn{2}{c}{2000} & \multicolumn{2}{c}{2011} & \multicolumn{2}{c}{$\begin{array}{c}\text { Changes } \\
2000-2011\end{array}$} \\
\cline { 3 - 8 } & & Extent (ha) & $\%$ & Extent (ha) & $\%$ & $\begin{array}{c}\text { Extent } \\
\text { (ha) }\end{array}$ & $\%$ \\
\hline 1 & Agricultural land & 31.86 & 0.39 & 173.70 & 2.10 & 141.84 & 1.72 \\
2 & Grass and shrubs & 1203.66 & 14.56 & 1276.47 & 15.44 & 72.81 & 0.88 \\
3 & Water body & 12.78 & 0.15 & 13.77 & 0.17 & 0.99 & 0.01 \\
4 & Primary and secondary & 4861.17 & 58.79 & 4890.78 & 59.15 & 29.61 & 0.36 \\
5 & forests & 44.73 & 0.54 & 32.67 & 0.40 & -12.06 & -0.15 \\
6 & Fine plantations & 541.8 & 6.55 & 214.65 & 2.60 & -327.15 & -3.96 \\
7 & Built-up Land & 6.48 & 0.08 & 27.45 & 0.33 & 20.97 & 0.25 \\
8 & Open land & 966.33 & 11.69 & 1039.32 & 12.57 & 72.99 & 0.88 \\
9 & Cloud & 600.3 & 7.26 & 600.30 & 7.26 & 0.00 & 0.00 \\
& Total & 8269.11 & 100 & 8269.11 & 100 & 0.00 & 100 \\
\hline
\end{tabular}

Remarks: Minus (-) means a decrease

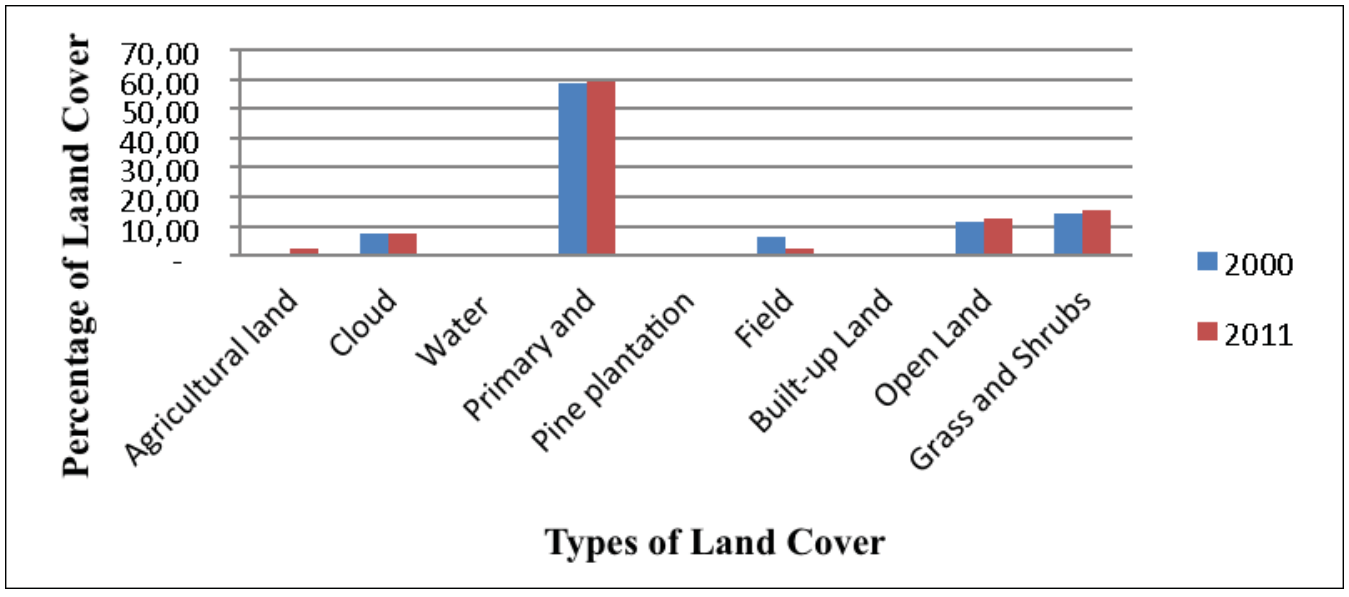

Figure 6. Graph Percentage of Land Cover/ Land Use Change in 2000 and 2011 
According to the result of Landsat Image in 2000-2011, the analysis of landcover change at Kamojang Nature Reserve has been showed off. The land cover type, such as forest still dominates the land cover in Kamojang Nature Reserve with area of 4,231.26 ha. The extent of deforestation in Kamojang Nature Reserve was 674.64 ha. Aside of that, to cope with the occurance of forest clearing,
PGE has reforested the land of Kamojang Nature Reserve. Reforestation has been done in Kamojang Nature Reserve by involving the people who live in surrounding area. The extent of reforestation and enrichment conducted by PGE was 680.58 ha. Land cover change in 2000-2011 periods are presented in Figure 7.

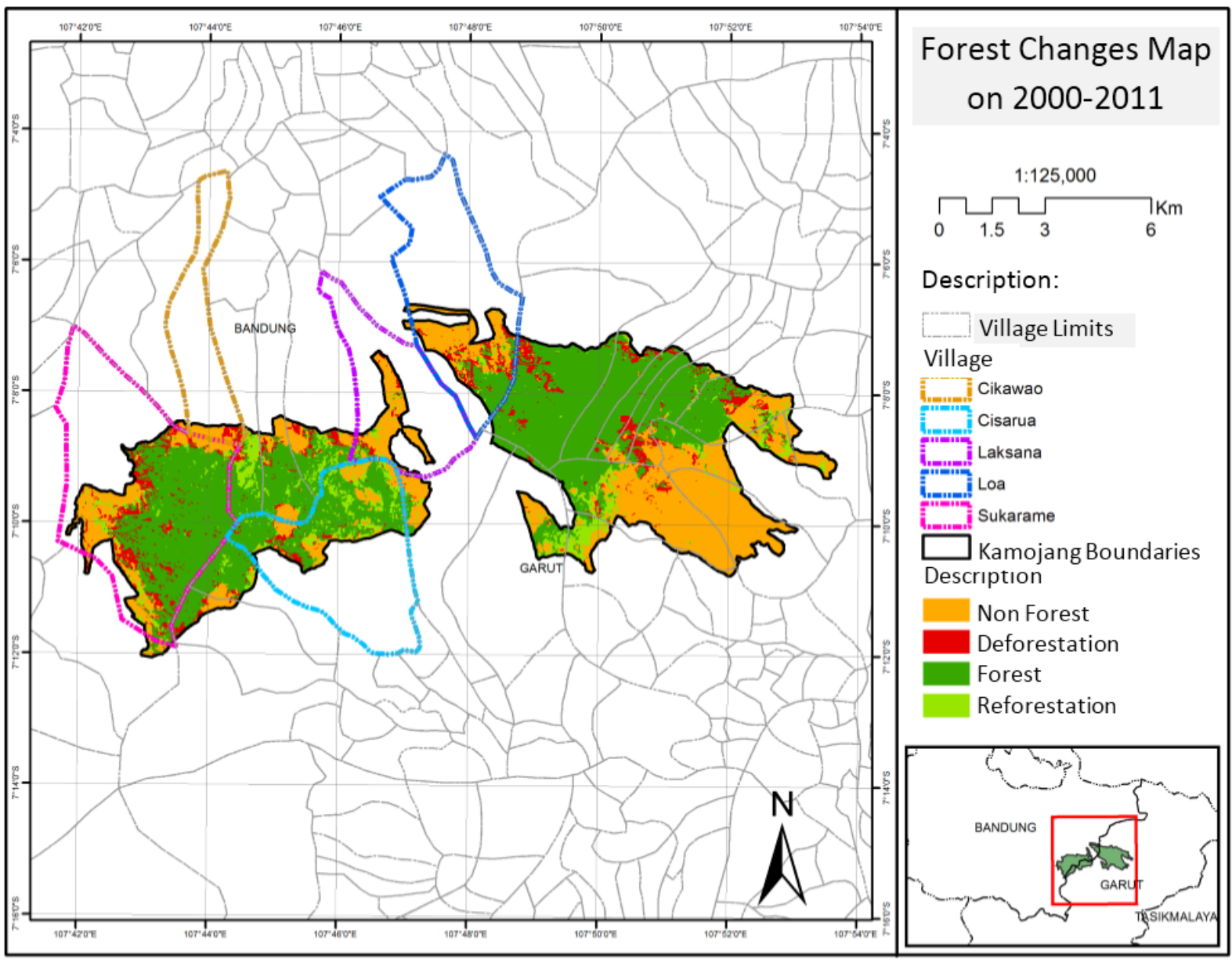

Figure 7. Land Cover/ Land Use Change in the Kamojang Nature Reserve in 2000-2011

\section{b. Deforestation During 2000-2011}

Panta et al. (2008) explained that the deforestation defined as a changing of forest cover to another land covers, meanwhile the degradation process needs a long process to become deforestation. According to Gilliba et al. (2011), socio economic factors influencing deforestation in the Bereku Forest Reserve were livelihood activities, period of residence and distance to the forest. While Mulyanto and Jaya (2004) stated that probability of forest degradation and deforestastion was influenced by the age of logged over forest, distance from the settlements, distance from the road and the river. Regarding the actor of deforestation, Table 3 describes the detail of deforestation which is doing by society and PGE. Deforestation by public (91.1\%) is much bigger than the deforestation by PGE (8.9\%). 
Table 3. Actor of Deforestation in the Kamojang Nature Reserve

\begin{tabular}{ccc}
\hline Actor & Extent $($ ha $)$ & Percentage $(\%)$ \\
\hline PT PGE & $60.18 * *)$ & 8.90 \\
Public & 614.46 & 91.10 \\
Total & $674.64 *)$ & 100.00 \\
\hline
\end{tabular}

Remarks: $*$ ) $=$ derived from satellite image analysis, $* *)=$ derived from PGE

Exploration and exploitation of geothermal energy requires the land clearing for some activities, such as drilling production wells and injection wells, construction of piping systems to drain the fluid to the power plant, the construction of geothermal power plant, and construction of access roads (Ditjen PHKA 2012). Land clearing by PGE that include the infrastructure building caused forest deforestation in Kamojang Nature Reserve untill 60.18 ha $(8.9 \%)$. Based on the guidelines on "lend-use system" ("sistem pinjam pakai") of Nature Reserve Kamojang, West Java II KSDA Great Hall, the utilization of geothermal use various locations that include the following: 1) Locations of "Kamojang Lama" about 30 ha for Kmj-VI, Kmj-II, KmjIII , Kmj-W, Kmj-DE/EE, Kmj-E/HH, Kmj-B/ DD, Kmj-C/GG, Kmj-G/II, Kmj-H/JJ, Kmj-I/ $\mathrm{KK}, \mathrm{Kmj}-\mathrm{EE} / \mathrm{FF}, \mathrm{Kmj}-\mathrm{N} / \mathrm{PP}, \mathrm{Kmj}-\mathrm{O} / \mathrm{QQ}, \mathrm{T} /$ $\mathrm{VV}, \mathrm{Kmj}-\mathrm{B}$ and piping systems; 2) Locations of Ciharus-A, CHR-A about 5.85 ha; 3) TVVD,E,F,G about 12 ha; 4) KWK A,B,C (Unit V) about 11.3 ha.

According to the interview, the deforestation in the Kamojang Nature Reserve possibly occurred from the constructions and infrastructure building inside the forest that stimulate the society easily enter to the forest. Kanninen (2009) revealed that the infrastructure building in the forest land, such as road construction, settlements, public facility, piping systems, and open mining was not the main factor of degradation. Otherwise, road building and infrastructure contributed the biggest effect to the deforestation. It would be influencing the activity in the remote area that caused expansion and deforestation. Trombulak and Frissel (2000) stated that in the tropics, land use trends such as forest conversion for agriculture and road construction result in increased human encroachment into forest, causing greater incidences of hunting and forest fragmentation. Similar to Gunawan and Prasetyo (2013) that the changes of forest area functions caused by access building and "lenduse system (sistem pinjam-pakai)" leads to the real fragmentation. Loss of trees which effect to the changing of vegetation structure and plants composition is an impact of the changes of forest area functions.

On the other hand, if we observed it by the satellite image, it can be concluded that the forest deforestation was getting worst by the society with area of 614.46 ha (91.1\%). Encroachment by society spread widely in many spots of forest area, without permission or without a strict supervision. In fact, the society tends to ignore the policy or rule in the forest land and don't have any responsibility after doing the encroachment. BKSDA has done various ways to cope with the problems, for instance dismissal claim, revocation of sweet potato plants, routine patrol, and expulsion the encroachment from the forest land. Suhendang (2002) stated that the encroachment and logging by the communities has not been accompanied by efforts to replant and maintenance of the logged - so the forest quality and species richness in that area much lower than a primary forest. Widada (2008) explained that if the conservation area was damaged, it was very difficult to recover, it would take a very long time and enormous costs. This condition has not been fully understood by the people surrounding conservation area, so that the behavior of a negative nature, like logging and forest encroachment was still happened.

In contrast with PGE activities, the land clearing caused the decreasing of area until 2 ha per cluster, especially in the determined area where the location contain a geothermal, and it also needs a long time of process for licensing. As we remembered that geothermal produces electricity by using science and modern technology so the human resource 
of PGE has knowledge about policy and rule in the conservation forest area. This understanding makes PGE more responsible.

\section{c. Reforestation During 2000-2011}

Beyond the land clearing by PGE can influence the ecological aspect, the presence of PGE has so much meaning to the society of surrounding geothermal projects. The presence of PGE can raise the supplemental income for people surrounding area, such as establish small shops, rented house, grocery shop and small restaurant. This fact is reinforced by the results of interview with managers PGE field of public services. PGE has empowered the community through the local labor with the number of human resources working in PGE Kamojang reached 287 people and income per month is Rp1 500 000. Similar to Wangke (2011), the impact of construction of geothermal projects is increasing in employment, population incomes, and the chances to open a small shop and the house rented.

To cope with the occurance of forest clearing, PGE has reforested the land of Kamojang Nature Reserve (See Table 4). Reforestation at primary and secondary forest was 659.16 ha and pine plantation was 21.42 ha. Pertamina also do replanting in cooperation with the Natural Resources Conservation Institute as outlined in forest management plans fiveyear conservation program (RKL 20102014). Chazdon (2013) explained that there were four different modes of reforestation: (a) spontaneous natural regeneration; (b) assisted natural regeneration; (c) agroforestry; and (d) commercial tree plantations. Natural regeneration fundamentally depends on the alignment of ecological and social factors at landscape scales. A deeper socioecological understanding of reforestation in the tropics will lead to the development of effective policies and governance structures that enhance forest cover and ecosystem services, protect biodiversity, and improve forestdependent livelihoods.
Nackoney and Williams (2012) stated that determining priority areas for conservation activities in the forests of the Congo Basin was increasingly important in the face of advancing human pressures and deforestation. As an effort to conserve the forest land and to prevent the human pressures in the future, reforestation also need to determine the planting area that include the type of trees, the ability to grow, how to plant, and how to manage the trees. As Grossnickle (2005) stated that root growth is critical to the establishment of planted seedlings. Seedlings can undergo stress just after planting if root growth is not sufficient to couple the seedling to available soil water. A newly planted seedling's ability to overcome planting stress is affected by its root system size and distribution, root-soil contact, and root hydraulic conductivity. The types of tree seedlings that developed in the programme of endemic nature wood planting, namely Suren (Toona sureni), Kibeureum (Saurauia cauliflora), Kayu Manis (Cinnamomum burmanii), Huru (Litsea glomerata), Kihonje (Pittosporum ferrugineum), Kihujan (Engelhardtia spicata), Manglid (Michelia velutina), Kibeusi (Rhodamnia cinerea), Kisalam (Eugenia cuprea), and Gelam/ Kayu putih (Melaleuca leucadendron).

In the Kamojang Nature Reserve, the extent of reforestation and enrichment conducted by PGE was 680.58 ha by involving the people who live in surrounding area. Even there was a payment services to the society that involve in the cultivation, this activity could raise the public awareness and a sense of belonging to the forest in the future. As Paranoan et al. (2012) revealed that payment service was given directly to the society in every activity of forest and land rehabilitation of Das Saddang, Tana Toraja Regency. Similar to Manjaribe et al. (2013) explained that reforestation effort in Kianjavato Commune in southeast Madagascar was presented that combines native diversity 
with rapidly growing introduced and native agroforestry development plans designed pioneer trees. The various contributions of to reduce pressure on forest resources and the community were described along with generate supplemental income.

Table 4. Corporate Social Responsibility Activity Conducted by PT PGE in the Kamojang Nature Reserve

\begin{tabular}{|c|c|c|c|c|c|c|c|}
\hline \multirow{2}{*}{ No } & \multirow{2}{*}{ Year } & \multirow{2}{*}{$\begin{array}{l}\text { Number } \\
\text { of plants }\end{array}$} & \multicolumn{2}{|c|}{ Condition } & \multirow{2}{*}{ Replanting } & \multirow{2}{*}{ Life } & \multirow{2}{*}{ Success $(\%)$} \\
\hline & & & Life & Dead & & & \\
\hline 1 & 1996 & 350 & 225 & 125 & 0 & 225 & $64.3 \%$ \\
\hline 2 & 1999 & 300 & 200 & 100 & 0 & 200 & $66.7 \%$ \\
\hline 3 & 2002 & 1,000 & 848 & 152 & 0 & 848 & $84.8 \%$ \\
\hline 4 & 2003 & 4,500 & 4,130 & 370 & 1,378 & 5,508 & $122.4 \%$ \\
\hline 5 & 2004 & 13,000 & 10,685 & 2,315 & 0 & 10,685 & $82.2 \%$ \\
\hline 6 & 2006 & 605 & 442 & 163 & 0 & 442 & $73.1 \%$ \\
\hline 7 & 2007 & 3,796 & 2,419 & 1,881 & 0 & 2,419 & $63.7 \%$ \\
\hline 8 & 2008 & 12,200 & 10,709 & 1,491 & 450 & 11,159 & $91.5 \%$ \\
\hline 9 & 2009 & 4,035 & 3,507 & 528 & 24 & 3,531 & $87.5 \%$ \\
\hline 10 & 2010 & 36,441 & 35,341 & 1,100 & 913 & 36,254 & $99.5 \%$ \\
\hline 11 & 2011 & 63,650 & 51,431 & 12,219 & 9,000 & 60,431 & $94.9 \%$ \\
\hline 12 & 2012 & 41,010 & 38,300 & 2,710 & 300 & 38,600 & $94.1 \%$ \\
\hline \multirow[t]{2}{*}{13} & 2013 & 5,400 & 5,400 & 0 & 0 & 5,400 & $100.0 \%$ \\
\hline & Total & 186,287 & 163,637 & 23,154 & 12,065 & 172,760 & $92.7 \%$ \\
\hline
\end{tabular}

Through the field of Corporate Social Responbility (CSR), PGE has been successfully made nurseries and replanting as shown in Table 6. Replanting was the plan of PGE because they have a great commitment to fix the current forest as good as the condition of nature forest. By involving the community, many efforts had been doing by PT PGE in order to empower the community and increase their independence and self awareness to the forest.

As Ristianasari (2013) stated as people living around protected areas, self-reliance in developing behavior in the field of ecology was very important. Society also agreed on the importance of preserving the area. However, people were still difficult to apply in terms of action, which means that with the knowledge, perceptions and good attitudes does not always bring up actions appropriate. This means that society becomes more aware, willing and able to implement positive things related preservation and improvement of the society welfare. Empowerment also should pay attention to the conservation efforts in the area of ecological, economic, social and cultural. Empowerment was also directed to increase the independence of the community that lead to a willingness to develop awareness, knowledge and skills to welfare.

\section{Conclusion and Recommendation}

The pressure on Nature Reserve Kamojang tends to increase due to a disturbance of the forest area, for instance the forest clearing, encroachment and logging. It has occurred the land cover change from 2000 to 2011 covering an area of $674.64 \mathrm{ha}$. There are two actors that lead to the disruption of the Kamojang Natur Reserve, PT PGE and society. Disruption of forest in Kamojang Nature Reserve as result of exploration and exploitation by PGE Kamojang 60.2 ha $(8.9 \%)$ and the encroachment and felling of trees by the public area of 614.46 ha $(91.1 \%)$. 


\section{References}

Casse, T., Milhoj, A., Ranaivoson, S. dan Randriamanarivo, J.R. (2002) Causes of Deforestation in Southwestern Madagascar: What Do We Know?. Journal of Forest Policy and Economics, $6,33-48$.

Chazdon. (2013) Making Tropical Succession and Landscape Reforestation Successful. Journal of Sustainable Forestry, 32:649-658. DOI:10.1080/10549811.2013.817340.

Dachlan, E.N., (2011) Kebutuhan Luasan Hutan Kota Sebagai Rosot (sink) Gas CO2 Untuk Mengantisipasi Penurunan Luasan RTH di Kota Bogor. Forum Geografi, Vol. 25, No. 2, Desember 2011: 164 - 177

Dhorde, A., Das, S., dan Dhorde, A. (2012) Evaluation of Land Use/Land Cover Change in Mula-Mutha Watershed, Pune Urban Agglomeration, Maharashtra, India, Based on Remote Sensing Data. Open access e-Journal Earth Science India, 5(3): 108-121.

Direktorat Jenderal Perlindungan Hutan dan Konservasi Alam. (2012). Kegiatan Evaluasi Kawasan Cagar Alam Kawah Kamojang.

Dwipayanti, U., Kastaman, R., dan Asdak, C. (2009). Model Dinamika Sistem Kerusakan Hutan di Kecamatan Ciemas Kabupaten Sukabumi. Prosiding Seminar Nasional Himpunan Informatika Pertanian Indonesia. ISBN:978-979-95366-0-7.

Entwisle, B., Rindfuss, R.R., Walsh, S.J., dan Page, P.H. (2008) Population growth and its spatial distribution as factors in the deforestation of Nang Rong, Thailand. Geoforum, 39(2):879-897. DOI: 10.1016/j.geoforum.2006.09.008.

Giliba, R.A., Boon, E.K., Kayombo, C.J., Chirenje, L.L., dan Musamba, E.B. (2011) The Influence of Socio-economic Factors on Deforestation: A Case Study of the Bereku Forest Reserve in Tanzania. Journal of Biodiversity, 2(1): 31-39.

Grossnickle, S. (2005) Importance of Root Growth in Overcoming Planting Stress. New Forests, 30:273-294. DOI:10.1007/S11056-004-8303-2.

Gunawan, H., dan Prasetyo, L.B. (2013). Fragmentasi Hutan: Teori yang Mendasari Penataan Ruang Hutan Menuju Pembangunan Berkelanjutan. Bogor: Pusat Penelitian dan Pengembangan Konservasi dan Rehabilitasi.

Gunawan, T. (2003) Utilization of Remote Sensing Techniques for Monitoring and Evaluation of Solo Watershed Management. J. Forum Geografi (17): 2 : 107-132.

Haeruman, H. (2005). Paradigma Pengelolaan Sumberdaya Alam Indonesia di Masa Mendatang: Konsep dan Pemikiran Prof. Dr. Ir. Herman Haeruman Js, MF. Bogor: Fakultas Kehutanan IPB.

Haryadi, B. (2009) Monitoring Dan Evaluasi Daerah Aliran Sungai Dengan Penginderaan Jauh Dan Sistem Informasi Geografis. J. Forum Geografi Vol. 23 No. 2, Desember 2009: 139152.

Hirsch, P. (1987) Deforestation and Development in Thailand. Singapore Journal of Tropical Geograph. 8(2) : 129-138.

Horowitz, L.S. (1997). Encroachment on Protected Areas by Small-Scale Actors: An Examination of the Issues. Washington DC: Study commissioned by Conservation International.

http://lipsus.kompas.com/samsungativ/read/2012/07/05/15111020/prioritaskan.panas.bumi. dalam.pengembangan.energi. 
Kelarestaghi, A., dan Jeloudar, Z.J. (2009) Land Use/ Cover Change and Driving Force Analyses in Parts of Northern Iran Using RS and GIS Techniques. Arabian Journal of Geosciences. 4:401-411. DOI 10.1007/s12517-009-0078-5.

Lindstrom, S., Mattsson, E., dan Nissanka, S.P. (2012) Forest Cover Change In Sri Lanka: The Role Of Small Scale Farmers. Applied Geography. 34: 680-692.

Lubis, J.P.G. dan Nakagoshi, N. (2011) Land Use and Land Cover Change Detection using Remote Sensing and Geographic Information System in Bodri Watershed, Central Java, Indonesia. Journal of International Development and Cooperation. 18(1): 139-151.

Lunetta, R.S., Congalton, R.G., Fenstermaker, L.K., Jensen, J.R., McGwire, K.C., dan Tinney, L. (1991) Remote Sensing and Geographic Information System Data Integration: Error Sources and Research Issues. Photogrammetric Engineering\&Remote Sensing, 57(6): 677-687.

Manjaribe, C., Frasier, C.L., Rakouth, B., dan Louis Jr., E.E. (2013) Ecological Restoration and Reforestation of Fragmented Forests in Kianjavato, Madagascar. International Journal of Ecology, Volume 2013 (2013), Article ID 726275, 12 pages. DOI: 10.1155/2013/726275.

Mulyanto, L., dan Jaya, I.N.S. (2004) Spatial Analysis on Forest Degradation and Deforestation : a Case Study in Duta Maju Timber, West Sumatera. Jurnal Manajemen Hutan Tropika, $\mathrm{X}(1): 29-42$.

Nackoney, J., dan Williams, D. (2012) Conservation Prioritization and Planning with Limited Widelife Data in a Congo Basin Forest Landscape: assessing human threats and vulnerability to land use change. Journal of Conservation Planning, 8: 25-44.

Nahib, I., dan Wijaya, J. (1998) Application of Remote Sensing and GIS for Monitoring and Evaluation of the Reforestation Activities in Kupang district of East Nusa Tenggara. J. Forum Geografi Vol 2 No. 1, 1998.

Nawir, M. (2011). Pemanfaatan Energi Panas Bumi Sebagai Potensi Penyedia Tenaga Listrik Regional. Sulawesi. Majalah Ilmiah Al-Jibra. ISSN 1411-7797, 12(39).

Panta, M., Kim, K., dan Joshi, C. (2008) Temporal Mapping of Deforestation and Forest Degradation in Nepal: Applicatons to Forest Conservation. Journal of Forest Ecology and Management, 256:1587-1595.

Paranoan, D., Paembonan, S.A., dan Millang, S. 2012. Pelaksanaan Program Rehabilitasi Hutan Dan Lahan (Studi Kasus: Program Gn-Rhl Bp-Das Saddang Kabupaten Tana Toraja).

Rachmawati. (2012) Prioritaskan Panas Bumi dan Pengembangan Energi [online]. dari: http:// lipsus.kompas.com/samsungativ/read/2012/07/05/15111020/prioritaskan.panas.bumi. dalam.pengembangan.energi [18 Juli 2013].

Reis, S. (2008) Analyzing Land Use/Land Cover Changes Using Remote Sensing and GIS in Rize, North-East Turkey. Sensors, 8:6188-6202. DOI: 10.3390/s8106188.

Ristianasari, Muljono, P., dan Gani, D.S. (2013) Impact of Empowerment Program on Conservation Village Model toward community Sustainability: Case at Bukit Barisan Selatan National Park, Lampung. Jurnal Penelitian Sosial dan Ekonomi Kehutanan, 10(3): $173-185$.

Rushayati, S.B., Alikodra, H.S.A, Dachlan, E.N. dan Purnomo, H. (2011) Pengembangan Ruang Terbuka Hijau Berdasarkan Distribusi Suhu di Kabupaten Bandung. Forum Geografi, Vol. 25, No. 1, Juli 2011: 17 - 26. 
Rushayati, S.B., Dachlan, E.N. dan Hermawan, R. (2010) Ameliorasi Iklim Melalui Zonasi Hutan Kota Berdasarkan Peta Sebaran Polutan Udara. Forum Geografi 24 (1).

Scrieciu, S.S. (2006) Can Economic Causes Of Tropical Deforestation Be Identified at a Global Level?. Ecological Economics, 62:603-612.

Suhendang, E. (2002). Pengantar Ilmu Kehutanan. Bogor: Yayasan Penerbit Fakultas Kehutanan IPB (YPFK).

Suryantoro, A. (2003) Easiness of Image Interpretation of Spot XS and Landsat TM for Urban Land Cover Object Identification. Forum Geografi Vol. 7 No. 1, 2003: 96-105.

Tahir, M., Imam, E., dan Hussain, T. (2013) Evaluation of Land Use/Land Cover Changes in Mekelle City, Ethiopia Using Remote Sensing and GIS. Computational Ecology and Software, 3(1):9-16.

Trombulak, S.C. dan Frissel, C.A. (2000) Review of Ecological Effects of Roads on Terrestrial and Aquatic Communities. Conservation Biology, 14: 18-30.

Wangke, W.M. (2010). Persepsi Masyarakat Terhadap Kegiatan Pengembangan Lapangan Uap dan PLTP Unit 5 dan 6 PT Pertamina Geothermal Energy. ASE, 6(3): 39-44.

Wangke, W.M. (2011). Dampak Sosial Ekonomi Kegiatan Pembangunan Proyek Lapangan Uap dan PLTP di Modayag Kabupaten Bolaang Mongondow Timur. ASE, 7(1): 33-37.

Widada. (2008). Mendukung Pengelolaan Taman Nasional yang Efektif Melalui Pengembangan Masyarakat Sadar Konservasi yang Sejahtera. Jakarta: Ditjen PHKA-JICA. 